\title{
Screening and evaluation of non-heterocystous filamentous cyanobacteria for lipid and commercially viable fatty acids
}

\author{
Indrama Thingujam ${ }^{1 *}$, Tiwari Onkar Nath ${ }^{1}$, Ojit Singh Keithellakpam ${ }^{1}$, Gunapati Oinam ${ }^{1}$, Avijeet Singh Oinam ${ }^{1}$, \\ Sarabati Kangjam ${ }^{1}$, Bidyababy Thiyam ${ }^{1}$, Indira Wangkhem ${ }^{1}$, Silvia Chungkham ${ }^{1}$, Subhalaxmi Aribam ${ }^{1}$, \\ Romi Khangembam ${ }^{1}$, Thadoi Angom ${ }^{1}$, Sharma Gauri Dutt ${ }^{2}$ \\ ${ }^{1}$ National Repository for Cyanobacteria and Microgreen algae (Freshwater), Microbial Resources Division, Institute of Bioresources and Sustainable \\ Development, (A National Institute of DBT, Govt. of India) Takyelpat, Imphal-795001, Manipur, India. ${ }^{2}$ Department of Life Sciences and Bio-informatics, \\ Assam University, Silchar-788011, Assam, India.
}

\section{ARTICLE INFO}

Article history:

Received on: 19/07/2015

Revised on: 16/08/2015

Accepted on: 29/08/2015

Available online: 22/10/2015

Key words:

Cyanobacteria, Fatty acids, Lipids, Non-heterocystous, Rice fields.

\begin{abstract}
Thirty eight unialgal non-heterocystous filamentous cyanobacteria were isolated from rice fields of Manipur, India; cultured as unialgal, deposited to the national repository of cyanobacteria and microalgae and obtained accession number. All these strains were screened and investigated for the production of total lipid and commercially viable fatty acids in culture condition. Equal amount of total lipid (3\%) was produced by Limnothrix vacuolifera BTA05, Plectonema boryanum BTA16, Plectonema nostocorum BTA47, Lyngbya laxespiralis BTA85 and Lyngbya norgardhii BTA184 in exponential growth phase. The commercially viable fatty acids, namely; palmitic acid (C16:0), palmitoleic acid (C16:1), oleic acid (C18:1n9c), linoleic acid $(\mathrm{C} 18: 2 \mathrm{n} 6 \mathrm{c})$ and $\gamma$ - linolenic acid (C18:3n6) were focused in present study. The investigation revealed that Plectonema notatum BTA88 yielded high content of palmitic acid (27.9\%); Oscillatoria agardhii BTA170 of palmitoleic acid (8.90\%); Lyngbya martensiana BTA640 of oleic acid (56.2\%); Phormidium faveolarum BTA20 (11.8\%) in linoleic acid and Phormidium boryanum BTA16 of $\gamma$ - linolenic acid (8.82\%). These organism were considered as the potential candidates for fatty acids profiling, however palmitic acid C16:0 was common and recorded in all 38 examined strains.
\end{abstract}

\section{INTRODUCTION}

Cyanobacteria, a large group of microorganisms in the prokaryotic kingdom, perform oxygenic photosynthesis using two photosystems that resemble those in the chloroplasts of eukaryotic plants. Cyanobacteria contain three glycolipids, monogalactosyldiacylglycerol, digalactosyldiacylglycerol and sulfoquinovosyldiacylglycerol, and a phospholipid, phosphatidylglycerol, as major glycerolipids. The lipid composition of most cyanobacteria is similar to that of the inner envelope membranes and thylakoid membranes of the chloroplasts of higher plants, and it is different from that of the membranes of most bacteria, which contain phospholipids as major glycerolipids. Besides nutritional value, the fatty acids of cyanobacteria are generally used to address taxonomical problems [1]. According to Kenyon [2] four types of fatty acids exist in cyanobacteria i.e. n-saturated, long chain saturated, unsaturated and long chain unsaturated and are linked to morphological characteristics. Lipids are esters of long fatty acids and alcohols that comprise a large group of structurally distinct

\footnotetext{
* Corresponding Author

Email:zenithindrama@gmail.com
}

organic compounds including fats, waxes, phospholipids, glycolipids etc. Cyanobacteria may contain significant quantities of lipids (fat and oil) with compositions similar to those of vegetable oils. The lipids of some cyanobacterial species are also rich in essential fatty acids such as the C18 linoleic (18:206) and $\gamma$ linolenic (18:3 03$)$ acids and their C20 derivatives,

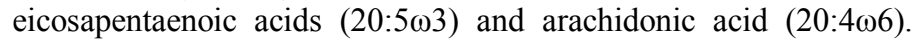
These fatty acids are essential components of the diet of humans and animals and are becoming important feed additives in aquaculture [3]. The lipids of cyanobacteria are generally esters of glycerol and long fatty acids. They may be either saturated or unsaturated. Some of the filamentous cyanobacteria tend to have large quantities (25 to $60 \%$ of the total) of polyunsaturated fatty acids [4-6]. Lipids (accumulated in the thylakoid membranes) are associated with high levels of photosynthesis and rapid growth rate and are of particular interest, since they can be used for biodiesel production [7-8]. Microalgae accumulate large amounts of lipids as reserve material, with especially in conditions of stress and slow growth [9]. The fatty acid composition of marine microalgae has been studied more extensively [10]; [11]; [12]; [13] than the freshwater forms [14]; [15]; [16]. Thus there is need to screen fresh water cyanobacteria for lipids of commercial value. Keeping this in mind the present work was undertaken. 
Table 1: Amounts of lipids and content of commercially viable fatty acids from non-heterocystous cyanobacteria.

\begin{tabular}{|c|c|c|c|c|c|c|}
\hline \multirow[b]{2}{*}{$\begin{array}{l}\text { Strains name with assigned code } \\
\text { from national repository }\end{array}$} & \multicolumn{6}{|c|}{ Content of total lipids and important fatty acids } \\
\hline & $\begin{array}{c}\text { Total lipid of dry } \\
\text { weight }\end{array}$ & $\begin{array}{c}\text { Palmitic acid } \\
\text { (C16:0) }\end{array}$ & $\begin{array}{c}\text { Palmitoleic } \\
\text { acid (C16:1) }\end{array}$ & $\begin{array}{l}\text { Oleic acid } \\
\text { (C18:1n9c) }\end{array}$ & $\begin{array}{c}\text { Linoleic acid } \\
\text { (C18:2n6c) }\end{array}$ & $\begin{array}{c}\gamma \text {-linolenic } \\
\text { acid }(\mathrm{C} 18: 3 n 6)\end{array}$ \\
\hline Phormidium тисоsит BTA02 & 1.00 & 2.89 & 2.89 & ND & 2.45 & ND \\
\hline Limnothrix vacuolifera BTA05 & 3.00 & 1.36 & 2.59 & ND & ND & ND \\
\hline Plectonema radiosum BTA09 & 1.70 & 1.34 & 3.06 & ND & 2.56 & ND \\
\hline Plectonema boryanum BTA10 & 2.00 & 0.42 & 0.18 & 11.6 & 2.61 & ND \\
\hline Phormidium tenиe BTA13 & 1.00 & 4.56 & 0.78 & 13.5 & ND & ND \\
\hline Phormidium boryanum BTA16 & 3.00 & 1.49 & 2.55 & 14.6 & ND & 8.82 \\
\hline Phormidium faveolarum BTA20 & 1.00 & 3.78 & ND & 11.8 & 11.8 & ND \\
\hline Plectonema radiosum BTA32 & 1.00 & 6.90 & 3.10 & 12.7 & ND & 7.89 \\
\hline Plectonema litorale BTA33 & 2.00 & 3.89 & 0.34 & 11.6 & 3.45 & ND \\
\hline Phormidium arthurensis BTA42 & 2.00 & 4.56 & 2.45 & 12.8 & ND & ND \\
\hline Plectonema nostocorum BTA47 & 3.00 & 1.15 & 0.44 & 14.6 & ND & ND \\
\hline Phormidium fragile BTA48 & 1.00 & 8.90 & 1.24 & 11.2 & 2.67 & 6.78 \\
\hline Phormidium purpurenscens BTA81 & 1.00 & 5.78 & 1.87 & 13.7 & ND & ND \\
\hline Limnothrix redekei BTA82 & 2.00 & 1.46 & 2.67 & ND & 6.89 & ND \\
\hline Phormidium kuetzingianum BTA83 & 1.00 & 3.67 & 2.89 & ND & ND & 5.56 \\
\hline Lyngbya laxespiralis BTA85 & 3.00 & 7.90 & 1.90 & 8.91 & 1.23 & ND \\
\hline Phormidium tenue BTA86 & 1.00 & 4.56 & 1.89 & 15.7 & ND & ND \\
\hline Plectonema notatum BTA88 & 2.00 & 27.9 & 1.12 & 14.7 & 2.65 & ND \\
\hline Plectonema notatum BTA108 & 2.00 & 7.66 & ND & 3.95 & 9.49 & 3.45 \\
\hline Phormidium incrustratum BTA118 & 1.00 & 2.91 & 3.43 & 3.56 & ND & 3.56 \\
\hline Limnothrix redekei $\mathrm{BTA} 123$ & 2.00 & 2.11 & ND & ND & ND & 2.56 \\
\hline Phormidium valderianum BTA162 & 1.00 & 0.85 & 2.82 & 2.67 & ND & ND \\
\hline Oscillatoria agardhii BTA170 & 1.00 & 0.90 & 8.90 & 2.34 & ND & ND \\
\hline Spirulina platensis BTA174 & 2.00 & 6.89 & ND & 4.45 & ND & 7.89 \\
\hline Lyngbya connectens $\mathrm{BTA} 178$ & 2.50 & 1.01 & 1.66 & 0.37 & ND & 0.64 \\
\hline Lyngbya norgardhii BTA184 & 3.00 & 1.34 & 1.23 & 9.91 & 8.09 & ND \\
\hline Phormidium tenие BTA194 & 2.00 & 2.32 & 4.56 & ND & ND & ND \\
\hline Plectonema notatum BTA199 & 1.00 & 6.17 & 2.41 & 4.90 & 9.67 & ND \\
\hline Limnothrix mirabilis BTA222 & 2.00 & 2.12 & 2.46 & 0.72 & ND & ND \\
\hline Phormidium tenиe BTA436 & 2.00 & 0.46 & 2.68 & 2.16 & ND & ND \\
\hline Lyngbya martensiana BTA436 & 2.00 & 0.98 & ND & ND & ND & ND \\
\hline Phormidium fragile BTA421 & 1.00 & 0.77 & 1.81 & 45.0 & ND & ND \\
\hline Plectonema notatum BTA565 & 2.00 & 0.51 & ND & ND & ND & 8.41 \\
\hline Phormidium autumnale BTA587 & 1.00 & 2.98 & 3.45 & 32.6 & ND & ND \\
\hline Lyngbya aestuarii BTA597 & 1.00 & 1.45 & 2.11 & 34.3 & 2.68 & ND \\
\hline Lyngbya allorgei BTA606 & 1.00 & 1.22 & 1.31 & 45.9 & ND & ND \\
\hline Lyngbya martensiana BTA640 & 2.00 & 1.34 & 4.79 & 56.2 & 2.90 & ND \\
\hline Phormidium stagnina BTA855 & 1.00 & 0.81 & 1.83 & 23.8 & 1.20 & 1.34 \\
\hline
\end{tabular}

*ND: not detected

\section{MATERIALS AND METHOD}

\subsection{Cyanobacterial strains isolation and cultivation}

A total of thirty-eight non-heterocystous filamentous cyanobacteria were investigated in this study. All strains were isolated from rice fields of Manipur, India. The strains were subjected to purification by plating, subculturing in sterile nitrogenous BG-11 agar medium [17].

Cultures were inoculated in $1000 \mathrm{ml}$ Erlenmeyer flasks containing $400 \mathrm{ml}$ of BG-11 nitrogenous medium and incubated at $28 \pm 2^{\circ} \mathrm{C}, 14 / 10 \mathrm{~h}$ light/dark cycle with light intensity of $50 \mu \mathrm{mol}$ photons $\mathrm{m}^{-2} \mathrm{~s}^{-1}$ under static conditions.

\subsection{Lipid extraction}

The most widely used derivatives were methyl esters by [18]. $15 \mathrm{ml}$ of $2 \% \mathrm{H}_{2} \mathrm{SO}_{4}$ in methanol solution was added to total biomass $(500 \mathrm{mg}$ ) in round bottom (RB) flask. RB flasks which contained biomass were refluxed in heating mantle at $60^{\circ} \mathrm{C}$ for $4 \mathrm{~h}$. FAME solution was transferred to a separating funnel then added50 $\mathrm{ml}$ ethyl acetate and $200 \mathrm{ml}$ distilled water to the FAME solution contained inside the separating funnel. Two layers were formed; the upper phase was retained and washed with distilled water till it gave a $\mathrm{pH} 7.0$ (checked through $\mathrm{pH}$ strip). The extract was separated into a conical flask, added $10 \mathrm{~g}$ sodium sulphate $\left(\mathrm{Na}_{2} \mathrm{SO}_{4}\right)$ into it and kept for $20 \mathrm{~min}$. Contents were transferred to $50 \mathrm{ml} \mathrm{RB}$ flask and rota-evaporated at $65{ }^{\circ} \mathrm{C}$. RB containing FAME was rinsed by addition of few drops of dichloro-methane and transferred the solution to a vial.

One $\mu \mathrm{l}$ of the sample was injected in GC using micro syringe (HAMILTON \# 701 USA) and Supelco ${ }^{\mathrm{TM}} 37$ FAME mix, Sigma-Aldrich was run as standard.

\subsection{Gas chromatography of FAME}

Methyl esterified samples were diluted with dichloromethane in the vial with micropipettes. Fatty acid profile was determined by the capillary column gas chromatrographic method. The sample $(1 \mu \mathrm{l})$ was injected into the gas chromatograph (Thermo Chemito Ceres 800 plus).

The samples were carried out using GC equipped with FID detector and forte capillary column $(60 \mathrm{~m} \times 0.32 \mathrm{~mm}$ I.D. $\times$ 
$0.25 \mu \mathrm{m}$ film thicknesses). The carrier gas was nitrogen used at a flow rate of $1.0 \mathrm{ml} / \mathrm{min}$. The run time of single sample was $60 \mathrm{~min}$. Fatty acids were identified and quantified by comparing the retention time and area of the authentic standards SupelcoTM 37 FAME mix (Sigma-Aldrich) and relative concentrations of different FAMEs and were calculated by the percentage area method using Chemito Chrom-card software version 2.6.

\section{RESULTS AND DISCUSSION}

Lipid profiling and fatty acid composition of thirty-eight (38) non-heterocystous filamentous cyanobacteria are presented in table 1. Photomicrographs are shown in photoplate 1 and 2 . Plectonema notatum BTA88 and Oscillatoria agardhii BTA170 showed high content of palmitic acid $(27.9 \%)$ and palmitoleic acid $(8.90 \%)$ respectively. Lyngbya martensiana BTA640 and Phormidium faveolarum BTA20 showed high content of oleic acid $(56.2 \%)$ and linoleic acid $(11.8 \%)$, respectively. Phormidium boryanum BTA16 yielded high amount of $\gamma$-linolenic acid $(8.82 \%)$ in culture conditions (table-1). Palmitic acid (C16:0), palmitoleic acid (C16:1), oleic acid (C18:1n9c), linoleic acid (C18:2n6c) and $\gamma$ - linolenic acid (C18:3n6) are to be highly valuable fatty acids for nutraceutical and pharmaceutical based industry.

In the present investigation, Phormidium faveolarum BTA020 and Phormidium boryanum BTA16 showed high content of linoliec acid, gamma linolenic acid which is very valuable for nutraceutical and pharmaceutical industry. The gamma linolenic acid (GLA) is reported as a promising therapeutic agent for numerous health disorders as it acts as a precursor for prostaglandin E1 an important compound necessary for reducing inflammation and in treatment of heart disease [19]; [20]; [21]. Most cyanobacteria are a common source of a wide range of fats, oils, hydrocarbons and sterols with potential not only as a renewable source of liquid fuels but also for the production of a range of pharmacologically and industrially important products. The applications of cyanobacteria in the production of these compounds are only just being explored.

New developments in the chemical industries, particularly in the area of converting natural products to industrial value, will further enhance the range of commercially important products synthesized by cyanobacteria.

\section{CONCLUSIONS}

The present study was focused mainly on extraction and evaluation of total lipid and fatty acid composition from nonheterocystous filamentous cyanobacteria isolated from rice fields of Manipur, India falling under Indo-Burma biodiversity hotspots. A total of 38 unialgal cultures were screened for lipid profiling and fatty acid composition.

These freshwater cyanobacteria are a source of essential fatty acids that are of commercial interest, including linoleic, and $\gamma$ - linolenic acids, among others. Further, some cyanobacteria serve as an important source of essential fatty acids for pharmaceutical and nutraceutical aspects.

\section{ACKNOWLEDGEMENTS}

The authors are very much thankful to the DST, Govt. of India for financial assistance and we express our sincere gratitude to the Director, DBT-IBSD, Imphal, Manipur for all kinds of support and help.

\section{REFERENCES}

1. Li R, Watanabe MM. Fatty acid profiles and their chemotaxonomy in planktonic species of Anabaena (cyanobacteria) with straight trichomes. Photochemistry. 2001; 57:727-731.

2. Kenyon CN. Fatty acid composition of unicellular strains of bluegreen algae. Journal of Bacteriology. 1972; 109:827-834.

3. Borowitzka MA, Borowitzka LJ. Microalgal biotechnology, Cambridge University Press, Cambridge. 1988; 477; 1988

4. Parker PL, Van Baalen C, Maurer L. Fatty acids in eleven species of blue-green algae: geochemical significance. Science. 1967; 155:707708.

5. Holton RW, Blecker HH. Fatty acids in blue-green algae. In: Zaick JE, editor. Properties and products of algae, New York: Plenum; 1972, p. 115-127.

6. Kenyon CN, Rippka R, Stanier RY. Fatty acid composition and physiological properties of some filamentous blue green algae. Archives of Mikrobiology. 1972; 83:216-236.

7. Karatay SE, Donmez G. Microbial oil production from thermophile cyanobacteria for biodiesel production. Applied Energy. 2011; 88:3632-3635.

8. Taher H, Al-Zuhair S, Al-Marzouqi AH, Haik Y, Farid MM. A review of enzymatic transesterification of microalgal oil-based biodiesel using supercritical technology. Enzyme Research. 2011; Article ID 468292.

9. Rittmann BE. Opportunities for renewable bioenergy using microorganisms. Biotechnology Bioengineering. 2008; 2:203-212.

10. Caudales R, Wells JM, Butterfield JE. Cellular fatty acid composition of cyanobacteria assigned to subsection II, order Pleurocapsales. International Journal of Systematic Evolutionary Microbiology. 2000; 50:1029-1034.

11. Renaud SM, Thinh LV, Parry DL. The gross composition and fatty acids composition of 18 species of tropical Australian microalgae for possible use in mariculture. Aquaculture. 1999; 170:147-159.

12. Tran H, Hong S, Lee C. Evaluation of extraction methods for recovery of fatty acids from Botryococcus braunii LB 572 and Synechocystis sp. PCC 6803. Biotechnology Bioengineering. 2009; 14:187-192.

13. Volkman JK, Jeffrey SW, Nichols PD, Rogers GI, Garland CD. Fatty acid and lipid composition of 10 species of microalgae used in mariculture. Journal of Experimental Marine Biology and Ecology.1989; 128:219-240.

14. Caudales R, Wells JM. Differentiation of the free-living Anabaena and Nostoc cyanobacteria on the basis of fatty acid composition. International Journal of Systematic Bacteriology.1992; 42:246-251.

15. Kruger GHJ, Wet HD, Kock JLF, Pieterse AJH. Fatty acid composition as taxonomic characteristic for Microcystis and other coccoid cyanobacteria (blue-green alga) isolates. Hydrobiologia. 1995; 308:145-151.

16. Rezanka T, Zahradnik J, Podojil M. Hydrocarbons in green and bluegreen algae. Folia Microbiologica. 1982; 27:450-454.

17. Stanier RY, Kunisawa MM, Cohen-Bazire G. Purification and properties of unicellular blue green algae (order Chroococcales). Bacteriology Reviews. 1971; 35:171-201.

18. Bligh EG, Dyer WJ. (1959). A rapid method for total lipid extraction and purification. Canadian Journal of Biochemistry and Physiology. 1957; 37:911-917.

19. Biagi PL, Bordoni A, Hrelia S, Celadon M, Horrobin DF. $\gamma-$ Linolenic acid dietary supplementation can reverse the aging influence on rat liver microsome 6-desaturase activity. Biochemical Biophysical Acta.1991; 1083:187-192. 
20. Ghazala B, Shameel M. Phytochemistry and bioactivity of some freshwater green algae from Pakistan. Pharmaceutical Biology. 2005; 43:358-369.

21. Wainwright PE, Huang YS, Levesque S, Mutsaers L, Mccutcheon D,Balcaen P, Hammond J. Effects of dietary $\gamma$ - linolenic acid and prenatal ethanol on mouse brain and behavior. Pharmacology Biochemistry Behavior. 1996; 53(4):843-852.

\section{How to cite this article:}

Indrama T., Tiwari O.N., Ojit S.K., Gunapati O., Avijeet S.O., Sarabati K., Bidyababy T., Indira W., Silvia Ch., Subhalaxmi A., Romi K., Thadoi A., Sharma G.D. Screening and evaluation of non-heterocystous filamentous cyanobacteria for lipid and commercially viable fatty acids. J App Biol Biotech. 2015; 3 (05): 011-014. DOI: 10.7324/JABB.2015.3502 